Abbreviated Key Title: Sch J Agric Vet Sci

ISSN 2348-8883 (Print) | ISSN 2348-1854 (Online)

Journal homepage: https://saspublishers.com

\title{
Growth and Yield Traits of Two Improved Cassava (Manihot esculenta Crantz) Cultivars under Poultry Manure and NPK Fertilizers
}

\author{
Kwadwo Gyasi Santo $^{1 *}$, Daniel Afreh Ntiamoah ${ }^{1}$, Patrick Mawuenyegan Norshie ${ }^{1}$, Abdulai Muntala ${ }^{1}$
}

${ }^{1}$ Department of Horticulture and Crop Production, School of Agriculture and Technology, University of Energy and Natural Resources, P. O. Box 214, Sunyani, Bono Region, Ghana

DOI: $10.36347 /$ sjavs.2021.v08i02.004

| Received: 09.02.2021 | Accepted: 20.02.2021 | Published: 28.02.2021

*Corresponding author: Kwadwo Gyasi Santo

\section{Abstract}

Studies to ascertain the effect of organic and mineral sources of N, P and $\mathrm{K}$ on growth and yield attributes of Bankyehemaa and Nkabom varieties were undertaken in Offinso, Ghana, from June, 2014 to May, 2015. The cassava varieties and 2 t/ha of poultry manure (PM), $600 \mathrm{~kg} / \mathrm{ha}$ each of NPK 15-15-15 and NPK 23-10-10, and a combination of the mineral fertilizers with PM at their half rates and a negative control were laid out in a factorial combination in a Randomized Complete Block Design with three replications. Plant height, number of roots per plant, mean root weight and root length were measured over the period, whereas height at first branching, shoot weight, stem girth and number of stems per hill were evaluated at final harvest at 11 months after planting (MAP). The data collected were subjected to analysis of variance using the $12^{\text {th }}$ Edition of GenStat Statistical package. Variety, fertilizer and treatment interaction effects for all the parameters measured were significant, except varietal effect on number of stems per plant, stem girth, mean root weight and root length. Growth and mean root number were increased in Bankyehemaa variety. NPK 23-10-10 alone increased number of roots per plant, while its combination with PM improved mean root weight and root length. This fertilizer combination increased root length in Nkabom variety. At final harvest, PM alone significantly improved mean root number in Bankyehemaa and also increased mean root weight in Nkabom. Cassava farmers should be encouraged to apply PM, NPK 23-10-10 and their combinations to improve the performance of Bankyehemaa and Nkabom varieties grown in sandy loams in a semi-deciduous forest ecology. In future studies, the impact of these fertilizers on soil physico-chemical properties and nutrient use efficiency of the test cassava varieties should be evaluated in multi-locations over many years.

Keywords: cassava, improved varieties, organic fertilizers, mineral fertilizers.

Copyright $(\mathcal{C}$ 2021: This is an open-access article distributed under the terms of the Creative Commons Attribution license which permits unrestricted use, distribution, and reproduction in any medium for non-commercial use (NonCommercial, or CC-BY-NC) provided the original author and source are credited.

\section{INTRODUCTION}

In Africa, cassava (Manihot esculenta Crantz) is the second most significant source of food calories consumed per capita [1]. Globally, the largest production of cassava occurs in sub-Saharan Africa (SSA). For instance, in 2013, Africa accounted for 57\% (158 million tons) out of the 277 million tons of cassava produced worldwide [2]. However, cassava is largely a subsistence crop cultivated for food by small-scale farmers with limited resources. It is increasingly realized that cassava is important for the future of Africa as it reduces food insecurity and hunger in the face of climate uncertainty and variability, provides cash income, supplies raw materials for local agrobased industries, and minimizes the cost of imports through substitution and/or biofuel production [3].
Cassava is highly adaptable and can grow well in a wide range of agro-ecological settings [4]. [5] reported that cassava crops are highly resilient in the face of current climatic variations. According to [6], resource-limited farmers who operate on marginal lands at the fringes of sensitive biodiverse habitats grow and manage cassava crops. Studies by [7] revealed that cassava crops grow well on low fertility soils and are advantageously flexible in time of harvest, making it the crop of 'last resort'.

[8] has supported complementary use of organic manure and inorganic fertilizers for providing sufficient amounts of plant nutrients required for sustaining maximum crop productivity and profitability while reducing environmental impact from nutrient use. The use of mineral fertilizer in combination with poultry manure has shown an increased yield as much as $60 \mathrm{t} / \mathrm{ha}$ of cassava roots [9]. 
Kwadwo Gyasi Santo et al., Sch J Agric Vet Sci, Feb, 2021; 8(2): 20-32

According to [10], high and sustained yield of cassava could be obtained with wise and combined application of mineral and organic fertilizers [11]. also indicated that quick mineralization of inorganic component and the slow nutrient release of the organic constituents of organo-minerals must have sustained the continuous better performance of Amaranthus cruentus than their sole applications. According to [12], combined application of organic and mineral fertilizers is a sound soil fertility management intervention worldwide [13]. Also suggested that an integrated nutrient management programme in which both organic and mineral fertilizers are applied is a rational strategy [14]. Found that the combined application will induce synchrony and decrease losses by converting inorganic nitrogen into organic forms.

According to [15], organic manures release their nutrients more slowly and this ensures a long residual effect [16]. found that improvement of environmental conditions and public health and the need to reduce costs of applying fertilizer to crops importantly support increased application of organic materials. According to [17], application of organic manures also improves the soil microbial properties. Work done by [18] depicted that organic manures are not frequently used due to their bulkiness, scarcity and high cost of conveyance. [19] found that animal manure tends to have low nutrient content less than $10 \%$ of that contained in most inorganic fertilizers, but they also contain $\mathrm{Ca}, \mathrm{Mg}, \mathrm{S}$ and some micronutrients not found in most inorganic fertilizers. In addition, they may improve the physical conditions of the soil. [20] reported that application of organic materials could maximize output of cassava since it enhances soil productivity and ensures higher fertilizer use efficiency. Work done by [21] showed that the amount of organic residues determines the quantity of organic matter in the soil.

Work done by [22] indicated that farmers are constrained with deficiencies of nutrients. He found that nutrient deficits are corrected through application of fertilizers. He also reported that output increases following application of mineral fertilizer [23]. reported that when application of mineral fertilizer is not preceded by soil test, the chemical and physical properties of soils are adversely affected. [24] and [25] showed that the application of mineral fertilizers continuously in the tropics could reduce crop yield, increase soil acidity and cause nutrient imbalance. According to [26], drawbacks associated with the use of mineral fertilizers are high cost, scarcity, misuse of chemical fertilizers and peasant farmers' misconception that inorganic fertilizers stimulate weeds, and vegetative growth rather than root formation and yield of poor qualities in terms of taste and shelf life [27]. showed that poundability of roots reduces following application of mineral fertilizers. They found that high cost of inorganic fertilizer and its associated bottlenecks have enhanced application of organic residues. They further reported that several studies conducted indicated positive effects of organic materials on soil productivity and that the use of organic manures is considered less likely to have adverse influence on soil physical and chemical properties relative to mineral fertilizers. According to [28], the sole use of mineral fertilizers has not been encouraging under intensive agriculture since it aggravates soil degradation. They found that the degradation is caused by loss of organic matter which eventually leads to soil acidity, nutrient imbalance and low productivity. They also showed that soil organic matter affects the response of crops to applied fertilizer.

The objective of the study was, therefore, to determine the effect of organic and mineral sources of $\mathrm{N}, \mathrm{P}$ and $\mathrm{K}$ on vegetative growth, number of roots per plant, root length and mean root weight of Bankyehemaa and Nkabom grown in sandy loams in a semi-deciduous forest in Ghana.

\section{MATERIALS AND METHODS Location of Research}

The field experiment (June, 2014 - May, 2015) was undertaken in Offinso municipality of the Ashanti Region of Ghana (6’45 N and 7'25 N, $1^{\circ} 65 \mathrm{~W}$ and $1^{\circ} 45$ $E$ with an elevation of $250 \mathrm{~m}-300 \mathrm{~m}$ above sea level). Offinso has a moist semi deciduous forest agro-ecology with a double maxima rainfall pattern [29]. A period of dry weather (December - March) separates the major rainy season (mid-March - end of July) and minor rainy season (September - mid-November). The area has a mean temperature range of $21^{\circ} \mathrm{C}$ to $30^{\circ} \mathrm{C}$. A maximum temperature of $30^{\circ} \mathrm{C}$ is experienced between March and April, and mean monthly temperature is about $27^{\circ} \mathrm{C}$. Annual rainfall ranges from $1500 \mathrm{~mm}$ to $1700 \mathrm{~mm}$. The relative humidity of the area increases in the major rainy season and reaches a peak of $90 \%$ between May and June. The soil of the area is mainly sandy loam. Tables 1 and 2 depict the physico-chemical characteristics of the soil at the experimental site. The rainfall and temperature figures of the study site during the 2014/2015 growing season are shown in Table 3. 
Table-1: Soil chemical properties of research location in 2014/2015 cropping season

\begin{tabular}{|ll|}
\hline \hline Chemical property & Level \\
\hline & \\
pH & 6.45 \\
Organic carbon (\%) & 1.71 \\
Organic matter (\%) & 2.95 \\
Nitrogen (\%) & 0.19 \\
Phosphorus (ppm) & 6.78 \\
Exchangeable cations (Cmol/kg) & \\
Potassium & 0.17 \\
Calcium & 4.81 \\
Magnesium & 1.60 \\
Sodium & 0.09 \\
EXC Acidity $(\mathrm{Al}+\mathrm{H})$ & 0.10 \\
CEC $(\mathrm{Cmo} / \mathrm{kg} / \mathrm{Me} / \mathrm{100g})$ & 6.77 \\
\hline
\end{tabular}

KNUST Soil Science Laboratory (2014)

Table 2: Soil physical properties of research location in 2014/2015 cropping season

\begin{tabular}{|lc|}
\hline Soil separates (\%) & \% Composition \\
Sand & 71.78 \\
Silt & 18.22 \\
Clay & 10.00 \\
Texture & Sandy loam \\
\hline
\end{tabular}

KNUST Soil Science Laboratory (2014)

Table-3: Temperature and rainfall figures at the research location during 2014/2015 cropping season

\begin{tabular}{|c|c|c|c|c|}
\hline \multirow[t]{2}{*}{ Month } & \multicolumn{2}{|c|}{ Temperature $\left({ }^{\circ} \mathrm{C}\right)$} & & \multirow{2}{*}{ Rainfall (mm) } \\
\hline & Max. & Min. & & \\
\hline June & 30.9 & 22.5 & & 206.5 \\
\hline July & 28.7 & 21.5 & & 103.7 \\
\hline August & 27.7 & 20.9 & & 10.2 \\
\hline September & 29.3 & 21.3 & & 56.7 \\
\hline October & 30.3 & 21.7 & & 163.6 \\
\hline November & 32.1 & 22.4 & $\cdot$ & 21.6 \\
\hline December & 32.1 & 21.8 & & 0.0 \\
\hline January & 33.4 & 17.8 & & 0.0 \\
\hline February & 33.4 & 22.2 & & 6.3 \\
\hline March & 33.5 & 22.2 & & 92.9 \\
\hline April & 33.3 & 22.8 & & 105.9 \\
\hline \multirow[t]{2}{*}{ May } & 32.7 & 22.9 & & 92.0 \\
\hline & & & & Total $=859.4$ \\
\hline
\end{tabular}

KNUST Animal Science Meteorological Station (2014/2015)

\section{Experimental design and Treatments}

Two cassava varieties (Bankyehemaa and Nkabom) grown with five sources of N, P and K and a control with no N, P and $\mathrm{K}$ were assessed in a factorial combination in a Randomized Complete Block Design (RCBD) with three replications. The sources of $\mathrm{N}, \mathrm{P}$ and $\mathrm{K}$ were as follows:

- Control (No fertilizer)

- $\quad$ NPK 15:15:15 at $600 \mathrm{~kg} / \mathrm{ha}\left(90 \mathrm{~kg} \mathrm{~N} \mathrm{ha}^{-1}\right.$; $90 \mathrm{~kg} \mathrm{P}_{2} \mathrm{O}_{5}$ ha $^{-1} ; 90 \mathrm{~kg} \mathrm{~K}_{2} \mathrm{O}^{-1}$ )
- $\quad$ NPK 23:10:10 at $600 \mathrm{~kg} / \mathrm{ha}\left(138 \mathrm{~kg} \mathrm{~N} \mathrm{ha}^{-1}\right.$; $60 \mathrm{~kg} \mathrm{P}_{2} \mathrm{O}_{5} \mathrm{ha}^{-1} ; 60 \mathrm{~kg} \mathrm{~K}_{2} \mathrm{O}$ ha $^{-1}$ )

- Poultry Manure (PM) at $2 \mathrm{t} / \mathrm{ha}(1.2 \% \mathrm{~N}$, $1.92 \% \mathrm{P}, 0.58 \mathrm{~K}, 5.10 \% \mathrm{Ca}, 5.10 \% \mathrm{Mg}$, $0.20 \% \mathrm{Na}, 1.75 \mathrm{pH})$

- $\quad 1 / 2 \mathrm{PM}+1 / 2$ NPK 15:15:15 (1/2 PM + 45kg N $\mathrm{ha}^{-1} ; 45 \mathrm{~kg} \mathrm{P}_{2} \mathrm{O}_{5}$ ha $\left.^{-1} ; 45 \mathrm{~kg} \mathrm{~K}_{2} \mathrm{O} \mathrm{ha}^{-1}\right)$

- $\quad 1 / 2 \mathrm{PM}+1 / 2$ NPK 23:10:10 (1/2 PM + 69kg N $\mathrm{ha}^{-1} ; 30 \mathrm{~kg} \mathrm{P}_{2} \mathrm{O}_{5}$ ha $^{-1} ; 30 \mathrm{~kg} \mathrm{~K}_{2} \mathrm{O} \mathrm{ha}^{-1}$ ) 
Table 4 shows characterization of the poultry manure used for the trial.

Table-4: Chemical properties of poultry manure used

\begin{tabular}{|cc|}
\hline Chemical property & Level \\
\hline $\mathrm{pH}$ & 1.75 \\
Total nutrients (\%) & \\
Nitrogen & 1.20 \\
Potassium & 0.58 \\
Calcium & 5.10 \\
Magnesium & 5.10 \\
Sodium & 0.20 \\
Phosphorus & 1.92 \\
\hline
\end{tabular}

KNUST Soil Science Laboratory (2014)

\section{Land preparation and crop management}

Clearing of the experimental site was initially done with a cutlass after which sunphosate (a systemic herbicide) was applied at the rate of $10 \mathrm{ml}$ per litre of water to control new flush of weeds. The site was then prepared into plots $(4.0 \mathrm{~m} \times 8.0 \mathrm{~m})$ with $1 \mathrm{~m}$ between plots and between blocks. Cassava stem cuttings were obtained from the cassava multiplication unit of the Ministry of Food and Agriculture, Asante Mampong. Each stake was about $20 \mathrm{~cm}$ long and had between 10 and 12 nodes. Stakes were planted in an angled orientation at $1 \mathrm{mx} 1 \mathrm{~m}$ on flat-tilled land on $2^{\text {nd }}$ June, 2014 to give a plant population of 10,000 plants/ha. There were 32 plants in each plot. Replacement of dead stakes was done at 2-3 weeks after planting depending on the availability of soil moisture.

Fertilizer was applied as per the treatments imposed. Scare-crows were used to control rodents, while termites were controlled with $\mathrm{K}$-othrine at the rate of $192.9 \mathrm{~kg} / \mathrm{ha}$ by broadcasting. Weeds were managed by hoeing as and when necessary during the first 8 weeks of growth until canopies were closed. Cassava tuberous roots were harvested at 11 months after planting.

\section{DATA COLLECTION}

Plant height $(\mathrm{cm})$ was measured at 3 months after planting (MAP) and subsequently every month up to 7 months after planting. Four plants from the middle row of each plot were chosen and tagged. The height of each of the plants was measured with a graduated pole from the ground level to the tip of the tallest leaf (terminal end of the plant). The average plant height was then recorded. The height $(\mathrm{cm})$ at first branching was also recorded using the four tagged plants per plot. Four plants were selected from each treatment and the dry weights of the shoot (leaves and stems) were determined by oven-drying them at a temperature of $80^{\circ} \mathrm{C}$ for 48 hours. The dry weight $(\mathrm{kg})$ of the shoot was repeatedly taken until a constant weight was obtained. The average dry shoot weight was then recorded. Four plants were selected from each treatment and the number of stems was counted. The average number of stems was then calculated. The diameter $(\mathrm{mm})$ of the stems per plant was taken with vernier calipers and the mean was calculated by summing up all the diameters of the stems and then dividing the total diameter by the number of stems per plant. Roots harvested from sampled plants were counted. The total number of roots was divided by the number of plants harvested per square metre per each treatment to get the mean number of roots. The length $(\mathrm{cm})$ of each root of four sampled plants was taken and the sum of the lengths was divided by the number of roots per plant sampled to obtain the mean root length. The total weight of the roots of four plants sampled was divided by the total number of roots to obtain mean root weight.

\section{DATA ANALYSIS}

Least Significant Difference (LSD) at 5\% probability level was used to separate treatment means after data were subjected to analysis of variance using the $12^{\text {th }}$ Edition of GenStat Statistical package [30].

\section{RESULTS \\ Plant height}

Results of plant height are presented in Table 5. The varieties differed significantly $(\mathrm{P}<0.05)$ in plant height at the first sampling period only, with Nkabom plants being taller than those of Bankyehemaa. The tallest plants were observed under plots treated with NPK 23-10-10 at the first sampling period, with the values statistically higher than $(\mathrm{P}<0.05)$ all other treatment means, except that of the NPK 15-15-15. All other treatment effects were similar. Application of NPK $15-15-15$ produced the taller plants $(\mathrm{P}<0.05)$ at the second, fourth and fifth sampling periods than all other fertilizer treatments, except the application of NPK 2310-10. The combined application of NPK 23-10-10 and poultry manure treatment effect was similar to that of NPK 15-15-15 treatment at 7 MAP. The control treatment effect was significantly $(\mathrm{P}<0.05)$ lower than all other treatment effects on all sampling days. There were significant treatment interaction effects for plant height on all the days of sampling. At harvest, application of NPK 15-15-15 to plants of Nkabom resulted in the tallest plants, whereas the shortest plants were observed in Nkabom plants not treated with fertilizer. 
Kwadwo Gyasi Santo et al., Sch J Agric Vet Sci, Feb, 2021; 8(2): 20-32

Table-5: Plant height for two cassava varieties under organic and inorganic sources of $\mathrm{N}, \mathrm{P}$ and $\mathrm{K}$ at different sampling periods in 2014/2015 cropping season

\begin{tabular}{|c|c|c|c|c|c|c|c|c|c|c|}
\hline \multirow[t]{3}{*}{ Fertilizer type } & \multicolumn{10}{|c|}{$\begin{array}{c}\text { Plant height }(\mathrm{cm}) \\
\text { Months After Planting }\end{array}$} \\
\hline & \multicolumn{2}{|c|}{3} & \multicolumn{2}{|c|}{4} & \multicolumn{2}{|c|}{5} & \multicolumn{2}{|c|}{6} & \multicolumn{2}{|c|}{7} \\
\hline & Var 1 & Var 2 & Var 1 & Var 2 & Var 1 & $\operatorname{Var} 2$ & Var 1 & Var 2 & Var 1 & $\operatorname{Var} 2$ \\
\hline F1 & 85.4 & 93.9 & 130.2 & 118.3 & 143.9 & 141.7 & 156.2 & 146.5 & 156.6 & 148.6 \\
\hline F2 & 95.7 & 125.0 & 140.3 & 166.7 & 178.8 & 193.9 & 218.3 & 227.3 & 220.3 & 229.4 \\
\hline F3 & 96.3 & 135.7 & 129.0 & 172.2 & 170.7 & 202.1 & 205.4 & 224.0 & 207.8 & 227.0 \\
\hline F4 & 96.4 & 98.8 & 132.7 & 133.0 & 164.2 & 162.2 & 186.7 & 189.5 & 188.8 & 191.9 \\
\hline F5 & 102.8 & 96.5 & 142.7 & 126.8 & 160.4 & 156.0 & 183.5 & 174.3 & 189.1 & 177.1 \\
\hline F6 & 109.4 & 81.6 & 150.7 & 123.0 & 174.0 & 152.3 & 217.8 & 198.4 & 220.1 & 204.8 \\
\hline $\operatorname{Var} 1$ & \multicolumn{2}{|c|}{97.7} & \multicolumn{2}{|c|}{137.6} & \multicolumn{2}{|c|}{165.4} & \multicolumn{2}{|c|}{194.6} & \multicolumn{2}{|c|}{197.1} \\
\hline $\operatorname{Var} 2$ & \multicolumn{2}{|c|}{105.3} & \multicolumn{2}{|c|}{140.0} & \multicolumn{2}{|c|}{168.0} & \multicolumn{2}{|c|}{193.3} & \multicolumn{2}{|c|}{196.5} \\
\hline F1 & \multicolumn{2}{|c|}{89.7} & \multicolumn{2}{|c|}{124.3} & \multicolumn{2}{|c|}{142.8} & \multicolumn{2}{|c|}{151.4} & \multicolumn{2}{|c|}{152.6} \\
\hline $\mathrm{F} 2$ & \multicolumn{2}{|c|}{110.4} & \multicolumn{2}{|c|}{153.5} & \multicolumn{2}{|c|}{186.4} & \multicolumn{2}{|c|}{222.8} & \multicolumn{2}{|c|}{224.9} \\
\hline F3 & \multicolumn{2}{|c|}{116.0} & \multicolumn{2}{|c|}{150.6} & \multicolumn{2}{|c|}{186.4} & \multicolumn{2}{|c|}{214.7} & \multicolumn{2}{|c|}{217.4} \\
\hline F4 & \multicolumn{2}{|c|}{97.6} & & & & & & & & .3 \\
\hline F5 & & & & & & & & & & 3.1 \\
\hline F6 & & & & & & & & & & 2.4 \\
\hline $\operatorname{Lsd}(p=0.05)$ & & & & & & & & & & \\
\hline Variety (V) & & & & & & & & & & \\
\hline Fertilizer (F) & & & & & & & & & & 96 \\
\hline $\mathrm{FxV}$ & & & & & & & & & & 33 \\
\hline $\mathrm{CV}(\%)$ & & & & & & & & & & 5 \\
\hline
\end{tabular}

Var 1: Bankyehemaa; Var 2: Nkabom; F1:Control; F2:NPK 15-15-15; F3:NPK 23-10-10

F4: Poultry manure (PM); F5: NPK 15-15-15 + PM; F6: NPK 23-10-10 + PM; NS: Not significant

\section{Fresh and dry shoot weight}

Fresh and dry shoot weights were both significantly $(\mathrm{P}<0.05)$ affected by variety and application of fertilizer (Table 6). The fresh shoot weight of the Bankyehemaa variety was significantly $(\mathrm{P}<0.05)$ higher than that of Nkabom. Among the fertilizer treatments, the NPK 15-15-15 treatment effect was the greatest, and this was significantly higher $(\mathrm{P}<0.05)$ than all other treatment effects, except those of NPK 23-10-10 alone and combined application of NPK 23-10-10 and the poultry manure. The control treatment effect was significantly lower $(\mathrm{P}<0.05)$ than all others, except the poultry manure only and combined application of NPK 15-15-15 and poultry manure.

Dry shoot weight was greater in Bankyehemaa variety than Nkabom variety. Among the fertilizer treatments, the NPK 15-15-15 treatment produced the greatest dry shoot weight, and this was similar to all other treatments, except the control and poultry manure. Combined fertilizer treatment effects were not significantly different from their respective fertilizer treatments. The control treatment effect was significantly lower $(\mathrm{P}<0.05)$ than the poultry manure alone and its combination with NPK 15-15-15.

There was significant variety by fertilizer type interaction effects for shoot weight. Combined application of poultry manure and NPK 23-10-10 to plants of Bankyehemaa recorded the highest fresh and dry shoot weights, while plants of Nkabom treated with no fertilizer had the lowest value. 
Kwadwo Gyasi Santo et al., Sch J Agric Vet Sci, Feb, 2021; 8(2): 20-32

Table-6: Fresh and dry shoot weights at harvest for two cassava varieties under organic and inorganic sources of $\mathrm{N}, \mathrm{P}$ and $\mathrm{K}$ in 2014/2015 cropping season

\begin{tabular}{|c|c|c|c|c|c|}
\hline \multirow[t]{2}{*}{ Fertilizer Type } & & \multicolumn{2}{|c|}{$\begin{array}{l}\text { Fresh shoot wt. } \\
\text { (kg/plant) }\end{array}$} & \multicolumn{2}{|c|}{$\begin{array}{l}\text { Dry shoot wt. } \\
\text { (kg/plant) }\end{array}$} \\
\hline & & Var 1 & $\operatorname{Var} 2$ & $\operatorname{Var} 1$ & Var 2 \\
\hline F1 & & 13.39 & 3.57 & 2.68 & 0.71 \\
\hline $\mathrm{F} 2$ & & 15.22 & 11.47 & 3.04 & 2.29 \\
\hline F3 & & 12.37 & 12.95 & 2.47 & 2.59 \\
\hline F4 & & 13.00 & 7.90 & 2.60 & 1.58 \\
\hline F5 & & 12.36 & 9.53 & 2.47 & 1.91 \\
\hline F6 & & 17.42 & 6.66 & 3.48 & 1.33 \\
\hline Vạr 1 & & \multicolumn{2}{|c|}{13.96} & \multicolumn{2}{|c|}{2.79} \\
\hline $\operatorname{Var} 2$ & $\cdot$ & \multicolumn{2}{|c|}{8.68} & \multicolumn{2}{|c|}{1.74} \\
\hline F1 & & \multicolumn{2}{|c|}{8.48} & \multicolumn{2}{|c|}{1.69} \\
\hline $\mathrm{F} 2$ & & \multicolumn{2}{|c|}{13.34} & \multicolumn{2}{|c|}{2.67} \\
\hline F3 & & \multicolumn{2}{|c|}{12.66} & \multicolumn{2}{|c|}{2.53} \\
\hline F4 & & \multicolumn{2}{|c|}{10.45} & \multicolumn{2}{|c|}{2.09} \\
\hline F5 & & \multicolumn{2}{|c|}{10.95} & \multicolumn{2}{|c|}{2.19} \\
\hline F6 & & \multicolumn{2}{|c|}{12.02} & \multicolumn{2}{|c|}{2.41} \\
\hline \multicolumn{6}{|l|}{$\operatorname{Lsd}(p=0.05)$} \\
\hline Variety (V) & & \multicolumn{2}{|c|}{1.44} & \multicolumn{2}{|c|}{0.29} \\
\hline Fertilizer (F) & & \multicolumn{2}{|c|}{2.49} & \multicolumn{2}{|c|}{0.50} \\
\hline $\mathrm{F} \times \mathrm{V}$ & & \multicolumn{2}{|c|}{3.53} & \multicolumn{2}{|c|}{0.70} \\
\hline $\mathrm{CV}(\%)$ & & \multicolumn{2}{|c|}{18.40} & \multicolumn{2}{|c|}{18.40} \\
\hline
\end{tabular}

Var 1: Bankyehemaa; Var 2: Nkabom; F1: Control; F2:NPK 15-15-15; F3:NPK 23-10-10

F4: Poultry manure (PM); F5:NPK 15-15-15 + PM; F6: NPK 23-10-10 + PM; NS: Not significant

\section{Stem girth, number of stems per plant and height at first branching \\ Stem girth were similar $(\mathrm{P}>0.05)$ in both} varieties. Fertilizer application significantly $(\mathrm{P}<0.05)$ influenced stem girth. The control treatment effect was significantly $(\mathrm{P}<0.05)$ lower than all other treatment effects. Application of NPK 23-10-10 resulted in significantly greater stem girth than all other fertilizer treatments. All other treatment differences were not significant (Table 7). There was significant variety by fertilizer type interaction effects for stem girth. The interaction between NPK 23-10-10 and plants of Bankyehemaa gave the highest stem girth, while interaction between Nkabom and the control (no fertilizer) treatment resulted in the lowest stem girth.

Number of stems per hill was not significantly $(\mathrm{P}>0.05)$ affected by variety, but application of fertilizer significantly $(\mathrm{P}<0.05)$ influenced it. Combined application of NPK 23-10-10 and poultry manure treatment produced the greatest numbers, which were significantly higher $(\mathrm{P}<0.05)$ than the control treatment effect only. All other treatment effects were not significant (Table 7). There were significant variety by fertilizer type interaction effects for number of stems per plant. Combined application of NPK 23-10-10 and poultry manure to plants of Bankyehemaa culminated in the highest number of stems per plant, while untreated plants of Nkabom variety had the lowest number of stems per plant.

The cassava variety and application of fertilizer had significant effect $(\mathrm{P}<0.05)$ on height at first branching. Plants of Bankyehemaa branched earlier than those of Nkabom variety. Height at first branching was lowest in combined application of NPK 23-10-10 and poultry manure which was significantly $(\mathrm{P}<0.05)$ lower than that of the sole application of NPK 15-1515. All other treatment differences were not significant (Table 7). The interaction between variety and fertilizer type was significant for height at first branching. Application of poultry manure alone to plants of Bankyehemaa decreased height at first branching, while sole use of NPK 15-15-15 in plants of Nkabom increased height at first branching. 
Kwadwo Gyasi Santo et al., Sch J Agric Vet Sci, Feb, 2021; 8(2): 20-32

Table-7: Stem girth, number of stems per plant and height at first branching for two cassava varieties under organic and inorganic sources of $N, P$ and $K$ at different sampling periods in 2014/2015 cropping season

\begin{tabular}{|c|c|c|c|c|c|c|}
\hline \multirow[t]{3}{*}{ Fertilizer type } & \multirow{2}{*}{\multicolumn{2}{|c|}{ Stem girth (mm) }} & \multirow{2}{*}{\multicolumn{2}{|c|}{$\frac{\text { Number of stems }}{\text { per plant }}$}} & \multirow{2}{*}{\multicolumn{2}{|c|}{ branching $(\mathrm{cm})$}} \\
\hline & & & & & & \\
\hline & Var 1 & Var 2 & Var 1 & $\operatorname{Var} 2$ & Var 1 & Var 2 \\
\hline F1 & $\overline{39.55}$ & 39.05 & 2.00 & 1.92 & 82.30 & 86.50 \\
\hline F2 & 45.23 & 52.60 & 2.08 & 2.17 & 84.20 & 110.00 \\
\hline F3 & 57.97 & 53.28 & 2.00 & 2.17 & 79.00 & 97.50 \\
\hline F4 & 46.68 & 49.05 & 2.00 & 2.00 & 73.90 & 104.80 \\
\hline F5 & 47.75 & 47.15 & 2.08 & 2.08 & 97.00 & 83.20 \\
\hline F6 & 48.05 & 43.15 & 2.25 & 2.17 & 80.50 & 87.60 \\
\hline $\operatorname{Var} 1$ & \multicolumn{2}{|c|}{47.53} & \multicolumn{2}{|c|}{2.07} & \multicolumn{2}{|c|}{82.80} \\
\hline Var 2 & \multicolumn{2}{|c|}{47.38} & \multicolumn{2}{|c|}{2.08} & \multicolumn{2}{|c|}{95.00} \\
\hline F1 & \multicolumn{2}{|c|}{39.30} & \multicolumn{2}{|c|}{1.96} & \multicolumn{2}{|c|}{84.40} \\
\hline F2 & \multicolumn{2}{|c|}{48.91} & \multicolumn{2}{|c|}{2.13} & \multicolumn{2}{|c|}{97.10} \\
\hline F3 & \multicolumn{2}{|c|}{55.61} & \multicolumn{2}{|c|}{2.08} & \multicolumn{2}{|c|}{88.30} \\
\hline F4 & \multicolumn{2}{|c|}{47.86} & \multicolumn{2}{|c|}{2.00} & \multicolumn{2}{|c|}{89.30} \\
\hline F5 & \multicolumn{2}{|c|}{47.45} & \multicolumn{2}{|c|}{2.08} & \multicolumn{2}{|c|}{90.10} \\
\hline F6 & \multicolumn{2}{|c|}{45.60} & \multicolumn{2}{|c|}{2.21} & \multicolumn{2}{|c|}{84.10} \\
\hline \multicolumn{7}{|l|}{ Lsd $(p=0.05)$} \\
\hline Variety (V) & \multicolumn{2}{|c|}{ NS } & \multicolumn{2}{|c|}{ NS } & \multicolumn{2}{|c|}{5.17} \\
\hline Fertilizer (F) & \multicolumn{2}{|c|}{5.25} & \multicolumn{2}{|c|}{0.16} & \multicolumn{2}{|c|}{8.96} \\
\hline $\mathrm{F} \times \mathrm{V}$ & & & & & & \\
\hline $\mathrm{CV}(\%)$ & & & & & & \\
\hline
\end{tabular}

Var1: Bankyehemaa; Var 2: Nkabom; F1:Control; F2:NPK 15-15-15; F3:NPK 23-10-10

F4: Poultry manure (PM); F5: NPK 15-15-15 + PM; F6: NPK 23-10-10 + PM; NS: Not significant

\section{Mean root weight}

Mean root weight did not vary significantly $(\mathrm{P}>0.05)$ between the two varieties on all the sampling periods. Application of fertilizer, however, significantly $(\mathrm{P}<0.05)$ influenced mean root weight on all the sampling occasions (Table 8). At 4 MAP, the control treatment effect was significantly $(\mathrm{P}<0.05)$ lower than all other treatment effects, except poultry manure treatment effect only. All other treatment effects were similar. At 6 MAP, the treatment effect of combined application of NPK $15-15-15$ and poultry manure was significantly higher $(\mathrm{P}<0.05)$ than all other treatment effects, except the treatment effects of the sole application of NPK 23-10-10 and poultry manure. All other treatment effects were not different. At 8 MAP, the greatest effect was recorded in the combined application of NPK $15-15-15$ and poultry manure, and this was significantly higher $(\mathrm{P}<0.05)$ than only NPK
15-15-15 treatment alone. All other treatment differences were not significant $(\mathrm{P}>0.05)$. At 11 MAP, the treatment effect of combined application of NPK 23-10-10 and poultry manure was significantly greater $(\mathrm{P}<0.05)$ than that of the other treatments, except that of the NPK 15-15-15 only treatment. The treatment effect of the control was lower than the treatment effects of NPK 15-15-15 alone and combined application of NPK 23-10-10 and poultry manure. All other treatment differences were not significant $(\mathrm{P}>0.05)$.

The interaction effect of variety and fertilizer for mean root weight was significant $(\mathrm{P}<0.05)$ at all the sampling periods. At harvest, the interaction between poultry manure alone and plants of Nkabom had the highest mean root weight, whereas the interaction between plants of Bankyehemaa and NPK 23-10-10 alone gave the lowest mean root weight. 
Kwadwo Gyasi Santo et al., Sch J Agric Vet Sci, Feb, 2021; 8(2): 20-32

Table-8: Mean root weight for two cassava varieties under organic and inorganic sources of $N$, $P$ and $K$ at different sampling periods in 2014/2015 cropping season

\begin{tabular}{|c|c|c|c|c|c|c|c|c|}
\hline \multirow{3}{*}{$\begin{array}{l}\text { Fertilizer } \\
\text { Type }\end{array}$} & \multicolumn{8}{|c|}{$\begin{array}{l}\text { Mean root weight }(\mathrm{kg}) \\
\text { Months After Planting }\end{array}$} \\
\hline & \multicolumn{2}{|c|}{4} & \multicolumn{2}{|c|}{6} & \multicolumn{2}{|c|}{8} & \multicolumn{2}{|c|}{11} \\
\hline & $\overline{\text { Var } 1}$ & Var 2 & Var 1 & Var 2 & Var 1 & $\operatorname{Var} 2$ & Var 1 & Var 2 \\
\hline F1 & 0.06 & 0.06 & 0.11 & 0.19 & 0.26 & 0.21 & 0.68 & 0.74 \\
\hline F2 & 0.09 & 0.09 & 0.14 & 0.42 & 0.36 & 0.91 & 0.76 & 0.73 \\
\hline F3 & 0.08 & 0.10 & 0.26 & 0.20 & 0.39 & 0.46 & 0.56 & 0.64 \\
\hline F4 & 0.08 & 0.08 & 0.26 & 0.58 & 0.43 & 0.57 & 0.64 & 0.91 \\
\hline F5 & 0.08 & 0.09 & 0.33 & 0.18 & 0.41 & 0.37 & 0.69 & 0.74 \\
\hline F6 & 0.08 & 0.10 & 0.23 & 0.19 & 0.54 & 0.46 & 0.78 & 0.82 \\
\hline Var 1 & \multicolumn{2}{|c|}{0.08} & \multicolumn{2}{|c|}{0.22} & \multicolumn{2}{|r|}{0.40} & \multicolumn{2}{|c|}{0.69} \\
\hline $\operatorname{Var} 2$ & \multicolumn{2}{|c|}{0.09} & \multicolumn{2}{|c|}{0.29} & \multicolumn{2}{|r|}{0.50} & \multicolumn{2}{|c|}{0.76} \\
\hline F1 & \multicolumn{2}{|c|}{0.06} & \multicolumn{2}{|c|}{0.15} & \multicolumn{2}{|r|}{0.24} & \multicolumn{2}{|c|}{0.71} \\
\hline F2 & \multicolumn{2}{|c|}{0.09} & \multicolumn{2}{|c|}{0.28} & \multicolumn{2}{|r|}{0.63} & \multicolumn{2}{|c|}{0.75} \\
\hline F3 & \multicolumn{2}{|c|}{0.09} & \multicolumn{2}{|c|}{0.23} & \multicolumn{2}{|r|}{0.42} & \multicolumn{2}{|c|}{0.60} \\
\hline F4 & \multicolumn{2}{|c|}{0.08} & \multicolumn{2}{|c|}{0.42} & \multicolumn{2}{|r|}{0.50} & \multicolumn{2}{|c|}{0.77} \\
\hline F5 & \multicolumn{2}{|c|}{0.09} & \multicolumn{2}{|c|}{0.25} & \multicolumn{2}{|r|}{0.39} & \multicolumn{2}{|c|}{0.72} \\
\hline F6 & & & & & & 0.50 & & \\
\hline $\operatorname{Lsd}(p=0.05)$ & & & & & & & & \\
\hline Variety (V) & & & & & & 0.05 & & \\
\hline Fertilizer (F) & & & & & & 0.09 & & \\
\hline $\mathrm{FxV}$ & & & & & & 0.13 & & \\
\hline $\mathrm{CV}(\%)$ & & & & & & 17.00 & & \\
\hline
\end{tabular}

Var 1:Bankyehemaa; Var 2:Nkabom; F1:Control; F2:NPK 15-15-15; F3:NPK 23-10-10

F4:Poultry manure (PM); F5:NPK 15-15-15 + PM; F6: NPK 23-10-10 + PM; NS: Not significant

\section{Number of roots per plant}

Both cassava variety and application of fertilizer significantly $(\mathrm{P}<0.05)$ affected number of tuberous roots per plant on all sampling occasions. Bankyehemaa variety produced higher number of tuberous roots per plant which was significantly $(\mathrm{P}<0.05)$ higher than that of Nkabom variety on each sampling day (Table 9).

The highest number of roots was produced following application of NPK 23-10-10 only at 4 MAP, and this was significantly higher $(\mathrm{P}<0.05)$ than all other treatment effects, except that of combined application of NPK 15-15-15 and poultry manure. The NPK 15-1515 only treatment effect was significantly higher $(\mathrm{P}<0.05)$ than those of the control and combined application of NPK 23-10-10 and poultry manure. At 6 MAP, the combined application of NPK 23-10-10 and poultry manure treatment effect was the highest, which was significantly higher $(\mathrm{P}<0.05)$ than all other effects, except those of NPK 15-15-15 and NPK 23-10-10 treatments. At 8 MAP, the NPK 15-15-15 only treatment effect was the highest, but this was significantly higher $(\mathrm{P}<0.05)$ than the control and combined application of NPK 15-15-15 and poultry manure treatments. At $11 \mathrm{MAP}$, mean number of roots was highest in NPK 23-10-10 only treatment, which was significantly higher $(\mathrm{P}<0.05)$ than the control treatment only. On all days of sampling, the control treatment effect was the least.

The interaction effect of variety and fertilizer for number of roots per plant was significant $(\mathrm{P}<0.05)$ on all the days of sampling. At harvest, sole application of poultry manure to plants of Bankyehemaa increased the number of roots per plant, while plants of Nkabom obtained from the control (no fertilizer) plots reduced number of roots per plant. 
Kwadwo Gyasi Santo et al., Sch J Agric Vet Sci, Feb, 2021; 8(2): 20-32

Table-9: Number of roots per plant for two cassava varieties under organic and inorganic sources of $\mathbf{N}, \mathbf{P}$ and $\mathrm{K}$ at different sampling periods in $2014 / 2015$ cropping season

\begin{tabular}{|c|c|c|c|c|c|c|c|c|}
\hline \multirow{3}{*}{$\begin{array}{l}\text { Fertilizer } \\
\text { Type }\end{array}$} & \multicolumn{8}{|c|}{$\begin{array}{l}\text { Number of roots per plant } \\
\text { Months After Planting }\end{array}$} \\
\hline & \multicolumn{2}{|c|}{4} & \multicolumn{2}{|c|}{6} & \multicolumn{2}{|c|}{8} & \multicolumn{2}{|c|}{11} \\
\hline & Var 1 & $\operatorname{Var} 2$ & Var 1 & Var 2 & Var 1 & Var 2 & Var 1 & Var 2 \\
\hline F1 & 6.67 & 6.08 & 7.58 & 5.25 & 8.08 & 6.33 & 14.58 & 8.50 \\
\hline F2 & 10.25 & 6.50 & 14.25 & 15.13 & 16.42 & 14.67 & 15.50 & 15.53 \\
\hline F3 & 12.33 & 9.42 & 11.25 & 16.58 & 12.42 & 16.42 & 16.50 & 16.58 \\
\hline F4 & 8.67 & 5.08 & 14.33 & 10.75 & 17.25 & 12.00 & 17.75 & 11.83 \\
\hline F5 & 12.50 & 6.08 & 10.67 & 11.25 & 11.17 & 12.58 & 16.00 & 14.75 \\
\hline F6 & 8.25 & 4.92 & 18.42 & 11.33 & 17.08 & 12.08 & 15.50 & 15.67 \\
\hline Var 1 & \multicolumn{2}{|c|}{9.78} & \multicolumn{2}{|c|}{12.75} & \multicolumn{2}{|c|}{13.74} & \multicolumn{2}{|c|}{15.97} \\
\hline $\operatorname{Var} 2$ & \multicolumn{2}{|c|}{6.35} & \multicolumn{2}{|c|}{11.72} & \multicolumn{2}{|c|}{12.35} & \multicolumn{2}{|c|}{13.81} \\
\hline F1 & \multicolumn{2}{|c|}{6.38} & \multicolumn{2}{|c|}{6.42} & \multicolumn{2}{|c|}{7.21} & \multicolumn{2}{|c|}{11.54} \\
\hline $\mathrm{F} 2$ & \multicolumn{2}{|c|}{8.38} & \multicolumn{2}{|c|}{14.69} & \multicolumn{2}{|c|}{15.54} & \multicolumn{2}{|c|}{15.52} \\
\hline F3 & \multicolumn{2}{|c|}{10.88} & \multicolumn{2}{|c|}{13.92} & \multicolumn{2}{|c|}{14.42} & \multicolumn{2}{|c|}{16.54} \\
\hline F4 & \multicolumn{2}{|c|}{6.88} & \multicolumn{2}{|c|}{12.54} & \multicolumn{2}{|c|}{14.62} & \multicolumn{2}{|c|}{14.79} \\
\hline F5 & \multicolumn{2}{|c|}{9.29} & \multicolumn{2}{|c|}{10.96} & \multicolumn{2}{|c|}{11.88} & \multicolumn{2}{|c|}{15.38} \\
\hline F6 & & & & & & & & \\
\hline $\operatorname{Lsd}(p=0.05)$ & & & & & & & & \\
\hline Variety (V) & & & & & & & & \\
\hline Fertilizer (F) & & & & & & & & \\
\hline $\mathrm{F} \times \mathrm{V}$ & & & & & & & & \\
\hline
\end{tabular}

Var 1:Bankyehemaa; Var 2:Nkabom; F1:Control; F2:NPK 15-15-15; F3:NPK 23-10-10

F4:Poultry manure (PM); F5:NPK 15-15-15 + PM; F6: NPK 23-10-10 + PM; NS: Not significant

\section{Root length}

Length of root of cassava did not vary significantly $(\mathrm{P}>0.05)$ between the two varieties, but fertilizer application significantly $(\mathrm{P}<0.05)$ affected it (Table 10). At 4 MAP, treatment effect of the NPK 23$10-10$ only was the greatest, and this was significantly higher $(\mathrm{P}<0.05)$ than all other treatment effects, except the combined application of NPK 23-10-10 and poultry manure treatment. The effect of the latter treatment was significantly higher $(\mathrm{P}<0.05)$ than that of the other treatments, except combined application of NPK 15-1515 and manure treatment. At 6 MAP sampling, treatment effects of NPK 15-15-15 only and poultry manure only were similar, but either effect was significantly higher $(\mathrm{P}<0.05)$ than all other treatment effects. At 8 MAP, effects of NPK 15-15-15 and poultry manure only treatments were similar, but the effect of the former treatment was greater than all other treatment effects. At 11 MAP, NPK 15-15-15 only and combined application of NPK 23-10-10 and poultry manure treatment effects were similar, and either effect was significantly higher $(\mathrm{P}<0.05)$ than all other treatment effects. On all days of sampling, the control treatment effect was the lowest.

The interaction between variety and fertilizer type was significant for root length. At harvest, combined application of NPK 23-10-10 and poultry manure to Nkabom plants produced longest roots, whereas Nkabom plants from the control (no fertilizer) plots gave the shortest roots. 
Kwadwo Gyasi Santo et al., Sch J Agric Vet Sci, Feb, 2021; 8(2): 20-32

Table-10: Root length for two cassava varieties under organic and inorganic sources of $\mathrm{N}, \mathrm{P}$ and $\mathrm{K}$ at different sampling periods in 2014/2015 cropping season

\begin{tabular}{|c|c|c|c|c|c|c|c|c|}
\hline \multirow{3}{*}{$\begin{array}{l}\text { Fertilizer } \\
\text { Type }\end{array}$} & \multicolumn{8}{|c|}{$\begin{array}{c}\text { Root length }(\mathrm{cm}) \\
\text { Months After Planting }\end{array}$} \\
\hline & \multicolumn{2}{|c|}{4} & \multicolumn{2}{|c|}{6} & \multicolumn{2}{|c|}{8} & \multicolumn{2}{|c|}{11} \\
\hline & Var 1 & Var 2 & Var 1 & Var 2 & Var 1 & Var 2 & Var 1 & Var 2 \\
\hline F1 & 19.11 & 20.04 & 24.63 & 24.00 & 29.28 & 23.21 & 39.29 & 40.21 \\
\hline $\mathrm{F} 2$ & 20.70 & 22.26 & 32.45 & 47.12 & 38.49 & 54.05 & 47.73 & 45.90 \\
\hline $\mathrm{F} 3$ & 29.42 & 30.58 & 37.05 & 27.50 & 43.91 & 38.23 & 39.61 & 43.50 \\
\hline F4 & 19.15 & 26.46 & 35.01 & 44.08 & 41.84 & 41.41 & 40.58 & 43.78 \\
\hline F5 & 23.72 & 25.47 & 34.32 & 25.70 & 40.96 & 41.31 & 45.48 & 38.38 \\
\hline F6 & 27.43 & 27.90 & 35.05 & 31.40 & 41.56 & 35.15 & 42.48 & 54.52 \\
\hline Var 1 & \multicolumn{2}{|c|}{23.26} & \multicolumn{2}{|c|}{33.08} & \multicolumn{2}{|c|}{39.34} & \multicolumn{2}{|c|}{42.53} \\
\hline $\operatorname{Var} 2$ & \multicolumn{2}{|c|}{25.45} & \multicolumn{2}{|c|}{33.31} & \multicolumn{2}{|c|}{38.89} & \multicolumn{2}{|c|}{44.38} \\
\hline F1 & \multicolumn{2}{|c|}{19.58} & \multicolumn{2}{|c|}{24.31} & \multicolumn{2}{|c|}{26.25} & \multicolumn{2}{|c|}{39.75} \\
\hline $\mathrm{F} 2$ & \multicolumn{2}{|c|}{21.48} & \multicolumn{2}{|c|}{39.78} & \multicolumn{2}{|c|}{46.27} & \multicolumn{2}{|c|}{46.81} \\
\hline F3 & \multicolumn{2}{|c|}{30.00} & \multicolumn{2}{|c|}{32.29} & \multicolumn{2}{|c|}{41.07} & \multicolumn{2}{|c|}{41.56} \\
\hline F4 & \multicolumn{2}{|c|}{22.81} & \multicolumn{2}{|c|}{39.55} & \multicolumn{2}{|c|}{41.62} & \multicolumn{2}{|c|}{42.18} \\
\hline F5 & \multicolumn{2}{|c|}{24.60} & \multicolumn{2}{|c|}{30.01} & \multicolumn{2}{|c|}{41.14} & \multicolumn{2}{|c|}{41.93} \\
\hline F6 & & & & & & & & \\
\hline $\operatorname{Lsd}(p=0.05)$ & & & & & & & & \\
\hline Variety (V) & & & & & & & & \\
\hline Fertilizer (F) & & & & & & & & \\
\hline $\mathrm{FxV}$ & & & & & & & & \\
\hline $\mathrm{CV}(\%)$ & & & & & & & & \\
\hline
\end{tabular}

Var 1: Bankyehemaa; Var 2: Nkabom; F1: Control; F2:NPK 15-15-15; F3:NPK 23-10-10

F4: Poultry manure (PM); F5:NPK 15-15-15 + PM; F6: NPK 23-10-10 + PM; NS: Not significant

\section{DISCUSSION}

\section{Treatment effects on vegetative growth}

Growth in cassava was measured as plant height, shoot weight, number of stems per hill, height at first branching and stem girth. Results of plant height as presented in Table 5 showed no significant differences between the varieties on all the sampling days, except on the first day of sampling where Nkabom variety significantly produced taller plants than those of Bankyehemaa variety. On all the sampling days, the nutrient-applied treatment effects were greater than the control probably because of steady supply of sufficient nutrients which could have culminated in high photosynthesis and efficient partitioning of dry matter to enhance cell elongation leading to vegetative growth. Additionally, poultry manure, apart from providing nutrients to plants, also improves soil structure through incorporation of organic matter, conservation of soil moisture and reduction in loss of water and plant nutrients [31]. In a similar study, [32] reported that the tallest plants resulted from application of poultry manure on Nkabom and IFAD varieties.

Differences between varieties in shoot weight were significant with plants of Bankyehemaa variety being heavier than those of Nkabom variety (Table 6). This may be due to greater vegetative components such as greater numbers of stems per hill and early branching with its associated increases in leaves and branch whorls as measured in the Bankyehemaa variety (Table 6). The early branching could also have exposed leaves and other green parts of the cassava plants to photosynthetically active radiation (PAR) for increased accumulation of photosynthates and its subsequent translocation [33]. All the fertilizer-applied treatment effects were invariably greater than those of the control treatment probably as a result of availability of nutrients by the former which certainly supported greater numbers of leaves, stems and branches. This corroborates findings of [34] who indicated that shoot biomass is greatly increased by application of fertilizer treatments than the control treatment.

The study showed that height at first branching was affected by both variety and application of fertilizer (Table 7). Bankyehemaa plants branched earlier than those of the Nkabom variety. This means that Bankyehemaa plants started branching at a shorter height and had many branching levels than those of Nkabom. The differences between the two varieties in this trait could be attributed to genetic variability. The result is in agreement with the findings of [35] and [36] that the system of stem branching is controlled by genetic and environmental factors. [37], in a similar observation, reported that the level of branching is contingent upon the cultivar of cassava. For the fertilizer treatments, the combined application of poultry manure and NPK 23-10-10 resulted in early branching.

The mean stem girth of $47.46 \mathrm{~mm}$ (Table 7) was similar to the findings of [38] who found that the diameter of a mature stem of cassava is within the range of 2 to $8 \mathrm{~cm}(20 \mathrm{~mm}-80 \mathrm{~mm})$. The biggest stem girth 
Kwadwo Gyasi Santo et al., Sch J Agric Vet Sci, Feb, 2021; 8(2): 20-32

per plant found under application of NPK 23-10-10 could be ascribed to availability of sufficient nutrients, especially nitrogen which could have led to a higher photosynthetic ability and an efficient partitioning of dry matter for vegetative growth. The result is consistent with the findings of [39] who reported that cassava responded to increased competition by diverting more dry matter to the stem.

The results (Table 7) showed that number of stems per plant was not significantly affected by variety, but was significantly affected by application of fertilizer. The highest number of stems per plant (2.21) was found in the combined application of poultry manure and NPK 23-10-10. The results could be attributed to adequate nutrient supply and improved soil conditions which could have culminated in high photosynthetic ability and efficient partitioning of dry matter for shoot growth.

\section{Treatment effects on yield attributes}

Mean root weight did not differ between the two varieties, but was significantly affected by application of fertilizer (Table 8). The fertilizer-treated plants produced greater mean root weights than the control treatment (Tables 8). The combined application of poultry manure and NPK 23-10-10 significantly produced the highest mean root weight. Organic manures reduce leaching and nutrients contained in them are released more steadily and slowly and are stored for a longer time in the soil, thereby ensuring a long residual effect [40]. This may have supported the formation of more and heavier tuberous roots following good vegetative growth which may have translated into better production and transfer of photosynthates.

The effects of variety and those of fertilizerapplied treatments for number of roots per plant were significant (Table 9). Bankyehemaa variety produced greater number of roots per plant than Nkabom on all the sampling days probably because of effective root initiation and tuberization following efficient translocation of assimilates to roots in the former than in the latter. This supports findings of [41] who observed that when more nodes are buried, more roots and stems are initiated. It is, therefore, likely that more stems and presumably leaves were available in the variety which would have culminated in a full canopy development leading to a larger photosynthetic surface to fill the larger number of roots produced and make them heavier as well. In a similar study, [42] reported that root bulking begins about 8 weeks after planting and that generally, the process of root initiation and bulking is affected by assimilate supply.

The fertilizer treatment effects for number of roots per plant were greater than the effect of the control treatment. Among the fertilized treatments, the effect of the application of NPK 23-10-10 alone was the greatest. The higher nitrogen content of the fertilizer treatment could have enhanced the uptake and usage of the phosphorus and potassium present in the added fertilizer which certainly could have supported the higher number of roots as they are essential in root formation. In their study, [43] observed that the significant increase in number of roots per plant has a positive correlation with fertilizer treatment.

Differences between varieties in root length were not significant, but application of fertilizer had a significant effect on it (Table 10). The effects of application of fertilizer were greater than the effect of the control treatment probably due to the loose and crumb soil structure that promoted root elongation as well as availability of nutrients, especially phosphorus and potassium which are essential for root formation and growth. For instance, potassium is useful for stimulating net photosynthetic ability of a leaf and increasing the translocation of photosynthates to the tuberous roots and also helps in the uptake of nitrates from the soil [44] and [45].

\section{CONCLUSION AND RECOMMENDATIONS Conclusion}

Bankyehemaa variety was relatively high in vegetative growth and had a significant increase in number of roots per plant. Generally, fertilizers improved growth and yield components of the varieties tested. NPK 23-10-10 alone improved stem girth in Bankyehemaa variety, while its combination with PM increased shoot weight and number of stems per plant in that variety. Sole application of NPK 23-10-10 increased number of roots per plant, while its combination with PM improved mean root weight and root length. This fertilizer combination increased root length in Nkabom variety. At harvest, sole application of PM significantly improved number of roots per plant in plants of Bankyehemaa and also improved mean root weight in Nkabom plants.

\section{RECOMMENDATIONS}

Poultry manure, NPK 23-10-10 and their combinations improved performance of both Bankyehemaa and Nkabom varieties grown in sandy loam soils in a semi-deciduous forest ecology. This field trial was conducted in one growing season in one location. It is, therefore, recommended that in future studies, the fertilizer types are tested on these cassava varieties and other improved ones in multi-locations over a number of years. Impacts of the fertilizers on some physico-chemical properties of soil should also be evaluated in future studies.

\section{REFERENCES}

1. Roothaert RL, Magado R. Revival of cassava product ion in Nakasongola District, Uganda. Int. J. Agric. Sustain. 2011; 9(1):76-81. 
Kwadwo Gyasi Santo et al., Sch J Agric Vet Sci, Feb, 2021; 8(2): 20-32

2. Bennett B. Guest editorial: smallholder cassava production and the cassava processing sector in Africa. Food Chain. 2015; 5:1-3.

3. Bennett B. Guest editorial: smallholder cassava production and the cassava processing sector in Africa. Food Chain. 2015; 5:1-3.

4. Delaquis E, de Haan S, Wyckhuys KAG. On-farm diversity of sets environmental pressures in tropical agro-ecosystems: a synthetic review for cassavabased systems. Agric. Ecosyst. Env. iron. 2018; 251:(Suppl. C.) 226-235.

5. Jarvis A, Ramirez-Villegas J, Campo BVH, Navarro-Racines C. Is cassava the answer to African climate change adaptation? Trop. Plant Biol. 2012; 5:9-29.

6. Delaquis E, de Haan S, Wyckhuys KAG. On-farm diversity of sets environmental pressures in tropical agro-ecosystems: a synthetic review for cassavabased systems. Agric. Ecosyst. Env. iron. 2018; 251:(Suppl. C.) 226-235.

7. El-Sharkawy MA. Global warming: causes and impacts on agroecosystems productivity and food security with emphasis on cassava comparative advantages in tropics/subtropics. Photosynthetica. 2014; 52(2):161-178.

8. John LW, Jamer DB, Samuel LT and Waner LW. Soil fertility and fertilizer: an introduction to nutrient management. Pearson Education. India, 2004; pp. 106-153.

9. CSIR-AgraProjects SHP. Soil Health Projects (SHP-014). 2012;

http://www.csirsoilresearch.org/Agra\%20Projects.h tm.

10. Kang BT and Balasubramanian V. Long Term Fertilizer Trials on Alfisols in West Africa. In: Transactions $14^{\text {th }}$ International Congress of Soil Science, Kyoto, Japan. August, 1990, 5:20-25.

11. Ipinmoroti RR and Adeoye GC. Effect of organic and NPK fertilizers on tea (Camellia sinesis) performance on a humid lowland ecological area of South western Nigeria. Proceedings of Horticultural Society of Nigeria Confrence, Ibadan, Nigeria. 2002: 69-74.

12. Lombin IG, Adepetu IA and Ayotade A. Complementary use of organic manures and inorganic fertilizer in arable production. Proceedings of National Organic Fertilizer Seminar Held at Durbar Hotel, Kaduna, Nigeria. 1991a;146.

13. Ayoola OT and Makinde EA. Fertilizer effects on performance of cassava under two planting patterns in cassava-based cropping systems in SouthWestern Nigeria. Research Journal of Agricultural and Biological Sciences. 2007a; 3(1):13-20.

14. Kramer AW, Doane TA, Horwath, WR and Kessel $\mathrm{CV}$. Combining fertilizer and organic inputs to synchronize $\mathrm{N}$ supply in alternative cropping systems in California. Agriculture, Ecosystem and Environment. 2002; 91:233-243.

15. Sharma AR and Mittra BN. Effect of different rates of application of organic and nitrogen fertilizers in rice-based cropping system. Journal of Agricultural Science (Cambridge). 1991; 117:313318.

16. Seifritz W. Alternative and renewable sources of energy in optimizing yields: The role of fertilizers. In: Proceedings of $12^{\text {th }}$ IPI Congress. 1982: 153163.

17. Belay A, Classens AS, Wehner, FC and Beer JM. Influence of residual manure on selected nutrient elements and microbial composition of soil under long term crop rotation. South Africa Journal of Plant and Soil Sciences. 2001; 18:1-6.

18. Nyathi P and Campbell BM. The Effect of tree leaf litter, manure, inorganic fertilizer and their combinations on above-ground production and grain yield of maize. African Crop Science Journal. $1995 ; 3(4): 451-456$.

19. Howeler RH. Response of cassava to VAM mychorizal inoculation. Plant and Soil Science. 1980; 69:327-339.

20. Santhi R and Selvakumari G. Use of organic sources of nutrients in crop production. In: Theme papers on Integrated Nutrient Management (eds.) Kannaiyan Published by Tamil Nadu Agric. University. Tamil Nadu Department of Agriculture. 2000: 87-101.

21. Agboola AA and Omueti JA. Soil fertility problem and its management in tropical Africa. Paper presented at the International Institute of Tropical Agriculture, Ibadan, Nigeria. 1982: 25.

22. Ojeniyi SO. Effect of bush clearing and tillage methods on soil physical and chemical properties of humid tropical alfisols. Soil and Tillage Research. 1990; 15:267-277.

23. Nottidge DO, Ojeniyi SO and Asawalam DO. Comparative effect of plant residue and NPK fertilizer on nutrient status and yield of maize in a humid ultisol. Nigerian Journal of Soil Science. 2005; 15:1-8.

24. Ojeniyi SO. Soil Management, Natural Resources and Environment. Adeniran Press. Ibadan. 2002: 30.

25. Mbah CN and Mbagwu JSC. Effect of animal wastes on Physico-chemical properties of a dystric Leptosol and maize yield in southern Nigeria. Nigerian Journal of Soil Science. 2006; 16:96-103.

26. Daramola B. The study of socio-economic factors influencing fertilizer adoption decisions in Nigeria. A survey of Oyo State farmers. Fertilizer Research. 1989; 20:143-151.

27. Bamire AS and Amujoyegbe BJ. Economic analysis of land improvement techniques in smallholder yam based production system in the agroecological zones of south western Nigeria. Journal Hum. Ecology. 2005; 18:1-12.

28. Sharma AR and Mittra BN. Effect of different rates of application of organic and nitrogen fertilizers in rice-based cropping system. Journal of Agricultural Science (Cambridge). 1991; 117:313318. 
Kwadwo Gyasi Santo et al., Sch J Agric Vet Sci, Feb, 2021; 8(2): 20-32

29. GSS. 2010 Population and Housing Census, National Analytical Report, 2012.

30. Payne RW, Murray DA, Harding SA, Baird DB, Soutar DM. GenStat for Windows (12 ${ }^{\text {th }}$ Edition) Introduction. VSN International, Hemel Hempstead, 2009.

31. Christopher PA, Viswajith V, Prabha S, Sundhar K and Malliga P. Effect of coir pith based cyanobacterial basal and foliar biofertilizer on Basellarubra L. Actaagriculturae Slovenica. 2007; 89(1):59-63.

32. Adoa HM. Growth, Yield and Quality of Cassava as Influenced by Terramend 21, Poultry Manure and Inorganic Fertilizer. Master of Agronomy Thesis, School of Graduate Studies, Kwame Nkrumah University of Science and Technology (KNUST), Kumasi. 2009.

33. Okogun JA, Sanginga N and Adeola EO. Soil fertility maintenance and strategies for cassava production in West and central Africa. IITA, Ibadan, Nigeria (Mineograph); 1999.

34. Sarfo H. Growth, yield and root quality of cassava as affected by application of organic and inorganic fertilizers. Master of Philosophy (Agronomy) Thesis, School of Graduate Studies, Kwame Nkrumah University of Science and Technology (KNUST), Kumasi. 2015; 83.

35. CIAT. Investigacion, produccion y utilizacion de yuca. Documento de trabajo. 1981; 50.

36. IITA. Cassava in Tropical Africa: A reference manual. International Institute of Tropical Agriculture, Ibadan, Nigeria. 1990; 176pp.

37. CIAT. Annual Report, 1978.Cassava Program. Cali, Colombia: Centro Internacional de Agricultura Tropical. 1979; 100 pp.
38. Ramanujam $\mathrm{T}$ and Indira P. Canopy structure on growth and development of cassava (Manihot esculenta Crantz). Turrialba. 1983; 33:321-326.

39. Cock JH, Franklin D, Sandoval G and Juri O. The ideal cassava plant for maximum yield. Crop Science. 1979; 19:271-279.

40. Tisdale SL, Nelson WJ and Beaton JD. Soil Fertility and Fertilizers. Macmillan Publishing Company. $4^{\text {th }}$ Edition, New York. Tolessa D and Friensen DK. Effect of enriching farmyard manure with mineral fertilizer on grain yield of Maize at Bako, Western Ethiopia. Seventh Eastern and Southern Africa Regional Maize Conference. $11^{\text {th }}$ $15^{\text {th }}$ February. 1993: 335-337.

41. Donkor SK. Investigation of suitability of the best cuttings and methods of planting cassava. (BSc. Dissertation.) Kumasi: University of Science and Technology; 1971.

42. IITA. Cassava in Tropical Africa: A reference manual. International Institute of Tropical Agriculture, Ibadan, Nigeria. 1990; 176.

43. Leo MV and Kabambe H. Potential to increase cassava yields through cattle manure and fertilizer application: Results from Bunda College, Central Malawi. Lilongwe University of Agriculture and Natural Resources. 2014; 45-65.

44. Akinsanmi O. Senior Secondary Certificate Agricultural Science. Longman Group Ltd. UK. 1999; 245 pp.

45. Brady NC and Weil RR. The Nature and Properties of Soils. $12^{\text {th }}$ Edition. Prentice Hall Inc., Upper Saddle River, New Jersy, USA. 1999; 881pp. 